J. Clin. Chem. Clin. Biochem.

Vol. 17, 1979, pp. 799-801

\title{
Isolation of Non-anticomplementary Human Immunoglobulin by Cohn Fractionation of Heated Plasma
}

\author{
By W. Stephan
}

BIOTEST-Serum-Institut GmbH, Frankfurt/Main

(Received December 19, 1977/Aügust 10, 1979)

Summary: Heat treatment of human plasma at $56^{\circ} \mathrm{C}$ eliminates an unstable immunoglobulin fraction. No anticomplementary activity is generated when the remaining heat-stable immunoglobulins are concentrated and purified by the Cohn alcohol method.

\section{Gewinnung von nicht antikomplementärem Human-Immunglobulin durch Coln-Fraktionierung von erhitztem Plasma}

Zusammenfassung: Durch Erhitzen von Human-Plasma auf $56^{\circ} \mathrm{C}$ wird eine unstabile Immunglobulinfraktion entfernt. Die im Plasma verbleibenden hitzestabilen Immunglobuline können durch Cohn'sche Alkoholfraktionierung isoliert werden, ohne daß während der Fraktionierung antikomplementäre Aktivität entsteht.

\section{Introduction}

Heat treatment of sera at $56^{\circ} \mathrm{C}$ for $30 \mathrm{~min}$, which is usually employed in serology to inactivate complement, causes partial aggregation of $\mathrm{IgG}$. When the immunoglobulins in such inactive sera are analyzed by gel filtration, aggregated IgG molecules appear in the $19 \mathrm{~S}$ fraction (1). Polymerization of immunoglobulins ạlso occurs when sera are kept at $63^{\circ} \mathrm{C}$ for $20 \mathrm{~min}$ at $\mathrm{pH} 7.0$ (2).

In the present work, standard conditions have been established for the elimination of heat-labile immunoglobulins from human plasma. The resulting plasma is a convenient source for the production of immunoglobulin preparations without anticomplementary activity.

\section{Măterial and Methods}

\section{Immunoeleçtrọphọresis}

Immunoelectrophoresis was performed according to the micromethod of Scheidegger (4) using antihuman rabbit sera (Medac, Hamburigig).

\section{Quantitative immunoelectrophoresis}

Quantitative immunoèlectrophộresis was carried out according to Stephan (5).

\section{Immunoglobulin determination}

The quantiplate of Messrs. Kallestad - distributed by Biotest, Frankfurt - was employed for determination of the immunoglobulins.

\section{Purification of immunoglobulins}

This was done according to the Cohn alcohol fractionation method as modified by Nitschmann \& Kistler (6). The alcohol was eliminated by a 24-hours dialysis against $9 \mathrm{~g} / 1 \mathrm{NaCl}$.

Anticomplementary activity

This was determined by the method of Kabat \& Mayer (7).

Immunoadsorption

Immunoadsorption by the heat-denatured proteins was carried out as follows: The precipitate from $1000 \mathrm{ml}$ recalcified and heated citrate plasma was washed 3 times with $50 \mathrm{ml} 9 \mathrm{~g} / \mathrm{l} \mathrm{NaCl}$, and subsequently 3 times with $50 \mathrm{ml} \mathrm{H}_{2} \mathrm{O}$; each washing was followed by centrifugation. After lyophilisation of this material, antihuman rabbit serum was added $(100 \mathrm{ml}$ per $4 \mathrm{~g}$ lyophilized material) and stirred at $37^{\circ} \mathrm{C}$ for 1 hour, then centrifuged. Quantitative immunoelectrophoresis was then performed.

\section{Results and Discussion}

Heat treatment of $\mathrm{IgG}$

If heat treatment at $63^{\circ} \mathrm{C}$ of human IgG is prolonged from $20 \mathrm{~min}$ to $40 \mathrm{~min}$ the polymeric fraction increases only slightly. Thus we did not polymerize the entire monomeric IgG-fraction at $63^{\circ} \mathrm{C}$, but only $50 \%$ of it (fig. 1). Furthermore, the monomeric fraction of immunoglobulin, heated at $63^{\circ} \mathrm{C}$ for $40 \mathrm{~min}$, shows the same low anticomplementary activity as the monomeric peak of the unheated starting material, whereas the polymeric fraction demonstrates an extremely high level of anticomplementary activity (fig. 2 , tab. 1). 


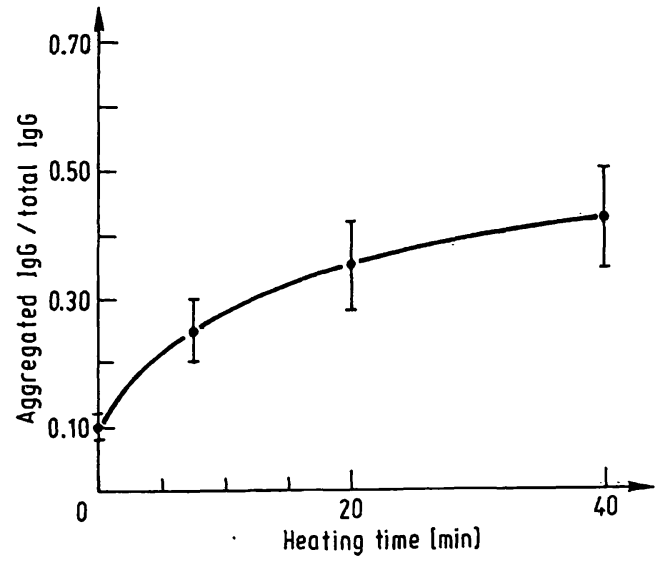

Fig. 1. Extent of aggregation of human immunoglobulin as a function of the time of heating at $63^{\circ} \mathrm{C}$.

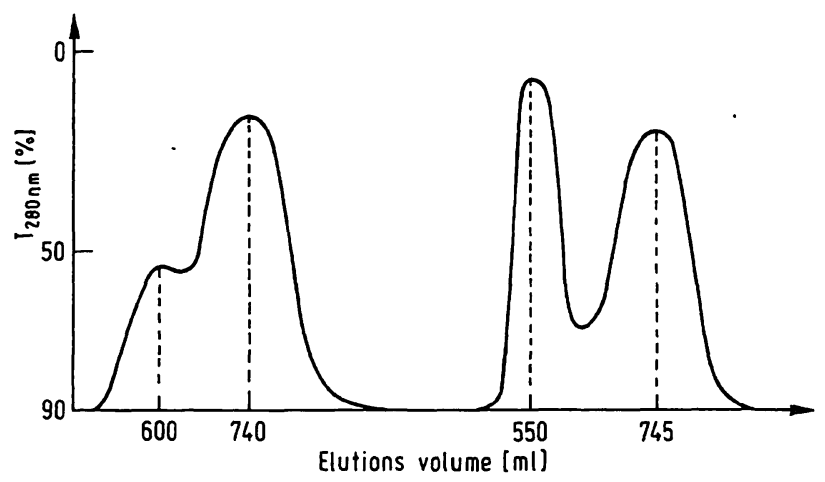

Fig. 2. Gel filtration of standard immunoglobulin on Sephadex G 150.

Left: normal immunoglobulin.

Right: immunoglobulin kept for $40 \mathrm{~min}$ at $63^{\circ} \mathrm{C}$.

Tab. 1. Anticomplementary activity of heated standard immunoglobulin.

\begin{tabular}{|c|c|c|}
\hline Product & $\begin{array}{l}\text { Anticompl } \\
\text { (reciprocal } \\
\text { polymers* }\end{array}$ & $\begin{array}{l}\text { tary activity } \\
\text { 7S IgG* }\end{array}$ \\
\hline $\begin{array}{l}\text { Standard immunoglobulin } \\
\text { (unheated) }\end{array}$ & 20 & 10 \\
\hline $\begin{array}{l}\text { Standard immunoglobulin } \\
\left(40 \mathrm{~min}, 63^{\circ} \mathrm{C}, \mathrm{pH} 7.0\right)\end{array}$ & 2000 & 10 \\
\hline
\end{tabular}

* Protein concentration: $25 \mathrm{~g} / \mathrm{l}$

Human plasma thus contains a fraction of immunoglobulins which are particularly heat-labile, and one may speculate that these immunoglobulins similarly aggregate when exposed to other denaturating conditions such as treatment in the Cohn fractionation procedure. This again would cause anticomplementary activity and in turn lead to the known problem of intravenous incompatibility of standard immunoglobulin (3). For this reason we tried to remove the heat-labile fraction by heating plasma.

\section{Heat treatment of plasma}

Human citrate plasma was heated at $56^{\circ} \mathrm{C}$ for different times, and the immunoglobulins were purified by the Cohn method. The various IgG-preparations were tested for anticomplementary activity. The results are summarized in tab. 2. It is clear from the data that the longer the plasma is heated, the lower is the anticomplementary activity of the corresponding preparation.

The precipitate formed in recalcified plasma during the heating process $\left(56^{\circ} \mathrm{C}\right.$ for 4 hours) consists mainly of IgG, IgA and IgM. This result was obtained by analyzing the immunoglobulin content of the supernatant (tab. 3). Approximately $20 \%$ of the total immunoglobulins are eliminated by the heat treatment. When the precipitate is used as an immuno-adsorbent for antihuman rabbit sera, mainly antibodies againșt IgG, IgA and IgM are absorbed (fig. 3). This shows that, apart from the well known heat precipitation of fibrinogen, it is mainly immunoglobulins that are precipitated by heating plasma at $56^{\circ} \mathrm{C}$.

Tab. 2. Complement consumption of human immunoglobulin from heated plasma.

\begin{tabular}{llr}
\hline $\begin{array}{l}\text { Heating } \\
\text { time }(\mathrm{h})\end{array}$ & $\begin{array}{l}\text { Complement }(1: 30) \\
\text { (ml/500 mg Immunoglobulin) }\end{array}$ & $\%$ \\
\hline 0 & 26 & 100 \\
$1 / 4$ & 14 & 54 \\
$1 / 2$ & 10 & 38 \\
1 & 3 & 12 \\
2 & 3 & 12 \\
3 & 1 & 4 \\
4 & 0 & 0 \\
\hline
\end{tabular}

Tab. 3. Immunoglobulin concentration in heated recalcified plasma.

\begin{tabular}{lcccc}
\hline Product & IgG & $\begin{array}{c}\text { IgA } \\
(\mathrm{mg} / \mathrm{l})\end{array}$ & IgM & $\begin{array}{c}\text { Total } \\
(\mathrm{mg} / \mathrm{l})\end{array}$ \\
\hline $\begin{array}{l}\text { Unheated plasma } \\
\text { Plasma kept for }\end{array}$ & 7750 & 1740 & 950 & 10440 \\
$4 \mathrm{~h}$ at $56^{\circ} \mathrm{C}$ & 6500 & 1280 & 750 & 8530 \\
\hline
\end{tabular}

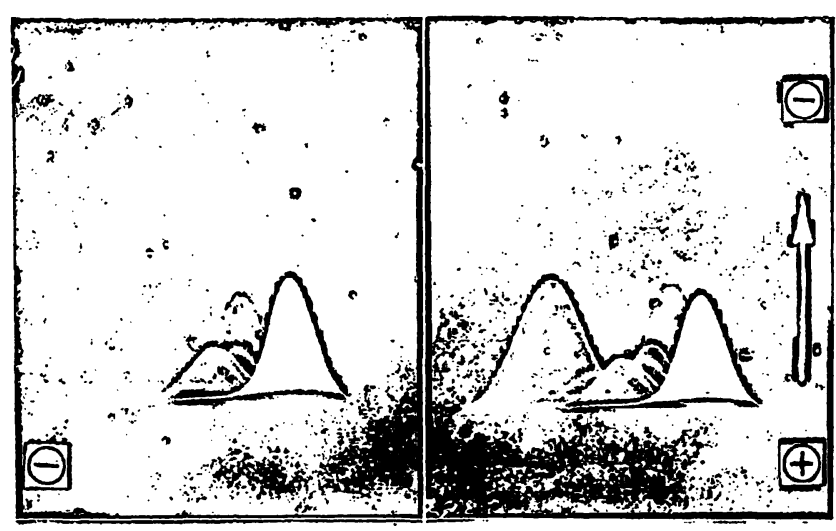

Fig. 3. Quantitative immunoelectrophoresis of human serum using antihuman rabbit serum.

Left: antihuman rabbit serum absorbed with precipitate of heat-treated plasma.

Right: unabsorbed antihuman rabbit serum. 


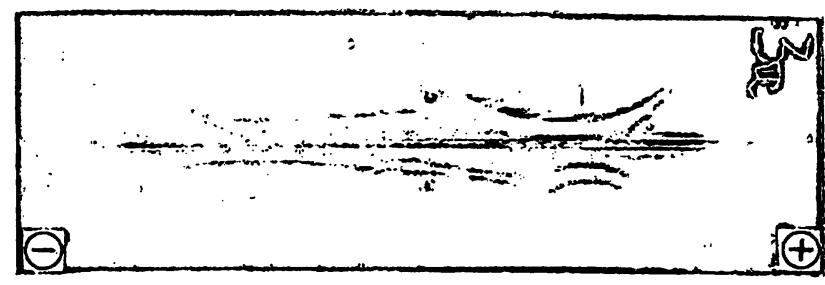

Fig. 4. Immunoelectrophoretic analysis of human serum (top) and IgG of heated plasma (bottom).

From pooled plasma, kept at $56^{\circ} \mathrm{C}$ for 4 hours, a $5 \%$ immunoglobulin solution can be produced whose anticomplementary activity and antibody activity is equivalent to those of the commercial IgG-preparations for intravenous use (tab. 4). The question, whether an immunoglobulin preparation of this type will be suitable for treatment of antibody deficiency syndromes, has to be answered by thorough clinical investigations.

\section{References}

1. Metzger, J.-J., Bourdieu, C., Rouze, P. \& Houdayer, M. (1975) J. Immunol. Meth. 8, 295-300.

2. Bier, O. G., Passos, H. C. \& Siqueira, M. (1968) Immunology 14, 291-298.

3. Barandun, S. (1964) Bibl. Haematol. (Basel) 17, 35-37.

4. Scheidegger, J. J. (1955), Int. Arch. Allergy 7, 103-110.

5. Stephan, W. (1974), Quantitative zweidimensionale ImmunElektrophorese auf Agarose-Gel. In: Serumproteine (Engl-
Tab. 4. Properties of IgG isolated from heated plasma.

\begin{tabular}{ll}
\hline pH-value & 6.9 \\
Protein concentration (g/l) & 50 \\
Purity (CAF) (\%) & 98.8 \\
Immunoelectrophoretic & Figure 4 \\
analysis & \\
7S fraction of immuno- & 90 \\
globulins (\%) & $600 \mathrm{I.U} . / \mathrm{ml}$ \\
Anti streptolysin & $1: 512$ \\
Anti rubella titre & Complement $(1: 30)$, \\
Anticomplementary activity & $2 \mathrm{ml} / 500 \mathrm{mg}$ immunoglobulin \\
\end{tabular}

\section{Acknowledgements}

I wish to thank Prof. Dr. G. May, Institute of Hygiene, Frankfurt/ Main, for the determination of antibodies. I am especially indebted to my coworkers Miss E. Haug, Mrs. B. Küßner, Mrs. R. Zeidler and Mr.P. Huszmann for the careful execution of the preparative and analytical work.

hardt, A. \& Lommel, H. eds.) S. 57-65, Verl. Chemie, Weinheim/Bergstraße.

6. Kistler, P. \& Nitschmann, H. (1962) Vox Sang. 7, 414-424.

7. Kabat, E. A. \& Mayer, M. M. (1964) Experimental Immunochemistry, 2nd Ed., chapt. 4, pp. 133-240 Charles C. Thomas, Springfield, Ill., USA.

Dr. W. Stephan Biotest-Serum-Institut $\mathrm{GmbH}$ Flughafenstr. 4 6000 Frankfurt 73 
